\title{
Function and Structure of European Economic Interest Group and Its Structural Difference with Multinational Companies
}

\author{
Masoumeh Rad Goudarzi ${ }^{1}$, Khashayar Esfandiari Far $^{2}$ \& Ardeshir Esfandiyari Far $^{3}$ \\ ${ }^{1}$ Faculty of Literature and Humanity, University of Guilan, Iran \\ ${ }^{2}$ Mofid University, Qom, Iran \\ ${ }^{3}$ University of Guilan, Rasht, Iran \\ Correspondence: Masoumeh Rad Goudarzi, Assistant Professor of Politics, Department of Political Science, \\ Faculty of Literature and Humanity, University of Guilan, Iran. E-mail: Fr.raad1@gmail.com
}

Received: October 2, 2014 Accepted: November 20, 2014 Online Published: February 12, 2015

doi:10.5539/ass.v11n5p121 URL: http://dx.doi.org/10.5539/ass.v11n5p121

\begin{abstract}
There are individuals and groups who have common interest in many areas, including political, economic, social and they are united together in order to achieve these benefits. One of the forms of this alliance in the economic sphere is forming an economic interest group. It has been so successful in economic development and progress and facilitating trade that goes beyond the boundaries and it has found a multinational nature in which European Economic Interest Group is one of the most important ones. On the other hand, we are facing with multinational companies which have more power and age in comparison to economic interest group. Whit the existence of multinational companies, the reason for existence of economic interest group is uncertain. In this study, researchers have examined the differences and benefits of these two institutions together and by examining the difference, function and structure of them, the reasons of economic interest group's importance in European Union are examined.
\end{abstract}

Keywords: European economic interest group, multinational companies, European Union, joint venture, cross-border cooperation

\section{Introduction}

For the first time in 1897, the idea of establishing financial institutions was introduced by an Italian lawyer called Fedozzi. He believed that these institutions have the potential to change into big companies which can result in the industry's rapid growth. Establishing European financial institutions that are not confined to the borders of a country were also introduced for the first time in 1959 by Thibierge in France at its fifty-seventh Parliament and Professor Peter Saunders, at the same year in the Netherlands, raised the issue during a speech at the Faculty of Economic in Rotterdam in the Netherlands (Storm, 1971, p. 1443). In December 1973 at the European Council, a plan known as "Proposal 1973" was introduced to establish uniform rules for the creation of an institution composed of different members of the European Union. On July 25, 1985, and referring to No. 2137.85, Legislative Council of Europe approved the relevant provisions of the European Economic Interest Group which consists of 43 articles and they have been implemented through European Union since July $1_{\mathrm{st}}$ in 1989. But before this, there was a similar institution in international law that has been same as the multinational companies. European Economic Interest Group is a form of an alliance between companies or other legal persons such as corporations established in various countries of European Union which need to corporate and work together beyond the national borders. Nearly 1,200 groups are working in different countries of European Union now. On the other hand, we are faced with multinational companies. Multinational or transnational economic unit is composed of companies with diverse nationalities. In other words, these companies are located in more than one country in nature and operation. It is expressed in some definitions that a company will be considered as a multinational company when headquarter or parent company which has the main role in its management, is owned by two or more countries (Ngomba-Roth, 2007, p. 87). A multinational company is consisting of a parent company and one or more subsidiary companies. Not only the parent company is connect with the company or foreign subsidiaries companies through stock ownership, management controlling, acquisition of majority of shares, voting rights or the right to appoint directors, but also it conducts their activities within the program frameworks of central office. 
The main question of the present study is that despite there are powerful multinational companies why it is needed to establish European Economic Interest Group and what is the structural and functional distinction between these two institutions. So in this paper, the researchers have examined the structure of European Economic Interest Group, and they have also studied its difference with multinational companies.

\section{The Existence Philosophy of Economic Interest Groups}

Economic interest group represents the relationship between two or more natural or legal persons that has been established for certain or uncertain duration. The purpose of this institution is to facilitate or develop the economic activities of its members and in addition, it improves related activities (Sitaru, 2011, p. 176). Several reasons have been proposed for the creation of an economic interest group:

The first reason was to use the economic potential throughout the European Union, irrespective of political boundaries so that all members of the European Union could use the EU market. The second reason for proposing this project was to create the adequate environment beyond the boundaries for large and small European trades people. And finally, the third reason was that in those years, there was no possibility of creating "European companies" in Europe continent for political reasons and hence under this plan, the European Union seeks to create a framework for making economic transactions outside the boundaries of countries, without establishing European companies. For this issue economic interest groups have been the appropriate framework and EEIG (Note 1) could be the formation of European companies.

An economic interest group has some advantages. One of these advantages is having legal personality which makes it possible for the group to contract and could be appealed and even could be the other side (e.g. the defendant). Capital is not needed to create a European Economic Interest Group. Group members may consider various and different financing ways and the rights and obligations will be expected by the contract that created the group. Another advantage of these groups is their tax transparency. The corporate tax is determined based on self-declaration by each member of these groups and according to the law governing them (Note 2). For example, tax for the European Economic Interest Groups in the United Kingdom is determined by the Finance Act approved in 1990. However, in the case of indirect taxes, these groups should act as a legal entity such as other financial institutions. Another advantage of these groups is their flexibility. This flexibility helps small companies to reach profitability by investments in these companies, because income and therefore the profitability of the small companies which are as group members will be increased by the accumulation of these small companies and enhancing their skills and service.

European Economic Interest Group is a means for cross-border cooperation between European Union countries and is aimed at expanding the economic activities of its members. Therefore the purpose of forming this group is that both natural persons and legal entities would be able to create an economic interest group to promote cross-border business activities and create a Joint Venture (Note 3) in other European countries. In fact, it can be said that the EEIG represents a financial agreement. A group in relation to its goals is mainly different from a company or a firm. Because a group just seeks to expand and enhance the ability of its members to achieve their goals. Because of the group's sub-face, group activities should be related to the economic activities of its members, but should not be replaced by the main activities of its members (Santa Maria, 2009, p. 174).

\section{The Rules Governing Economic Interest Group}

Economic interest group has provided a different method to communicate with other member countries without ignoring their individuality and independence. European Union has regulations in which member countries are allowed to impose specific requirements under the national law of the European Economic Interest Group. Therefore, there are some differences in the laws of Member States in areas such as legal entity, directors and audit requirements. The purpose of this regulation can be known as creating a harmonious development of economic activities across the European Union and creating a common market same as national market conditions, as well as decreasing psychological, financial and legal problems that natural and legal entity including Companies, firms and other institutions are encountered in line with across borders' cooperation (Note 4).

Regarding the important issue that which country's laws will govern the group's activities, it must be said that laws of the country in which the Economic Interest Group is registered govern the group. It should be noted that the European Union law also govern dissolution conditions of European Economic Interest Group and National Law Station of the European Economic Interest Group govern dissolution and purification mechanisms and processes. It should be also said about the regulation governing the multinational companies that about the mother company, the country of registration sets its regulations and the same rule also governs in the case of dependent companies because they should also act in other countries and according to the rules of the country 
where they are registered (Schmitthoff, 2011, p. 499). So the European Economic Interest Groups and multinational companies do not differ in this regard. The Economic Interest Groups like any other companies are also under the legislation concerning competition laws. In addition to national laws relating to competition laws, each of these groups is also governed by Articles 105 and 106 of the Treaty of Rome.

\section{Legal Entity and the Formation Condition of a Group}

The entity of a European Economic Interest Grouping apart from its international nature is exactly the same as the entity of multinational companies. However, there are certain characteristics because of the nature of the multinational groups. Granting legal entity to the EEIG causes that the group assumes some rights and obligations and this can include make a contract and/or the group can plead or be prosecuted.

A group establishing ways are very similar to the ways a company establishment. Members' agreement to form an economic group should include the group's name and this name must be specified on top of the workplace's panel, and in the name, legal form, and location of group members (Mesnooh, 1994, pp. 91-92). There are some necessary and prerequisite conditions for the creation of a European Economic Interest Grouping which include ganging up at least two merchants, whether a natural person or a legal entity from at least two different European countries. Because, if both of them belong to just one country, the formed group will be an economic interest grouping not a European Economic Interest Grouping.

It should also be emphasized that for the companies' membership in economic interest groups, either member companies should be created under the laws of one of the member countries in European Union or their management center should be in one of the European Union countries. In contrast, for the formation of a multinational company, at least two legal entities as Mother Company and Dependent Company are required and two natural individuals and/or a natural person and a legal person cannot form a multinational company. European Economic Interest Grouping only flows and forms between European countries; however, this limitation does not exist in multinational companies. A mother company in Europe, for example, can establish a subsidiary company in Asia.

Unlike conventional trade, the European Economic Interest Group and economic interest group are exempted from introducing any nominal capital (Note 5). If we are able to choose between a commercial mechanism and an economic interest group, this exemption can be considered as an advantage for economic interest group (Warner, 2005, p. 339).

\section{Citizenship and Home Center of a Group}

It should be said about the citizenship of a group that it is formed according to the one of the member states' law and it is registered in European Union and its headquarter should be in European Union. The home center of a group is a place where the group is established or where the original settlement of the group is there or where the main deployment of one of its members (legal entity) or its main activity (natural person) is there. However the home center of the group should be deployed in European Union. Registered groups in European Union may be transferred freely in European Union without having to create a new legal entity. In contrast, the home center of multinational companies is a place where the mother company is registered in that country and dependent companies will be a citizenship of a country where they are established (Schmitthoff, 2011, pp. 492-494).

\section{Management and Governance}

It should be said about the managers of European interest group that managers are appointed by group members and the group's members will also be able to restrict managers' power and authority. The only restriction that can be done by the members for the managers is in conjunction with the "Double signature" (Note 6); i.e., all managers should make a decision. The daily decisions of a group are made by the Director of the Department. At least one person should be selected in the group as a manager. It should be noted in the case whether the manager must be only a natural person or the legal person could be also a manager that Executive Board of the European Economic Interest Group in Germany which its official address is in Germany must be a natural person but in many European Union countries, legal entities like private firms with limited responsibilities or joint venture companies are allowed to be appointed as the manager of the group but a natural person must be designated as their representative; thus the manager can only be a natural person. Managers of economic interest groups have joint-liability responsibility for their activities. In multinational companies, all key and critical positions in corporate management in the core company are occupied by nationals of the country where the company is its subordinate. In foreign operations, the major tasks are also done by nationals of the same country and there is a permanent attention the security and political and economic stability in order to protect investments (Hussein, 2001, p. 37). 
The members of the EEIG decide how to handle it. Naturally this issue and the way of the managing print in the group statute, but there is no requirement that it should be included. There is no compulsion that the members decide only in the legal sessions but only members can take their decisions via fax, video conferencing, and phone. Each member has at least one vote. In the group formation contract (Constitution) can consider more than one vote to certain members of the group. (EEIG members who have a greater share in the share capital) And also can present that no one can have maximum votes. There are some decisions that fundamentally affect the existence of the group and its performance, taking these decisions needs unanimity of votes. These decisions include:

1. Change the group purpose,

2. Change the duration of group survival

3. Change the contribution of the members in relation to the group financing,

4. Change the members' commitment unless otherwise has stated in the statutes,

5. Transfer the group official address to another member of the European Union,

6. Change the number of votes allocated to each member.

\section{Type of Group Activity}

Economic interest group activities must be related to the economic activities of its members. The concept of economic activity can be interpreted very broadly. For example, research and academic institutions can become a member of a group of economic interest. But the Economic Interest Groups are prohibited from doing some works and cannot do these things:

1. European Economic Interest Group against the multinational company, cannot be formed with the aim of making a profit, though the benefits may be achieved as a result of its normal function (Note 7). Article 40 of the provisions relating to regulations of the Europe Council expressly confirmed this issue (Note 8).

2. This group is prohibited of exerting management control over the activities of its members or other responsible persons.

3. Shares of each member in the group is prohibited.

4. The public sector cannot invest in these groups.

5. This group cannot employ more than 500 people.

6. European Economic Interest Group cannot be a member of another group.

7. The group cannot lend to a company director or any person connected to him where prohibited or controlled by national law.

8. This group cannot be used for transferring any property between a company and a director or any person connected to him, except the area that the national law is allowed.

Most of the people (natural persons) and organizations, companies and firms (legal persons) who are active in the European Union, could become a member of this group and there is no limit on the number of members except in Ireland and Greece, which the maximum members of EEIG is limited to 20 people (Note 9). But it is a condition of membership in the group, each member must be engaged in an economic activity before his membership in this group, it means that the persons who want to be a member of this group, any industrial, commercial, skillful or agricultural activity they do and the professional services they provide should be realized in the European Union. Organizations that are located in non-EU Europe cannot be a member of this group. It should be noted that the European Economic Interest Groups can sign agreements with organizations and companies outside the EU but these organizations and companies cannot be a member of these groups. But for the formation and membership in the multinational companies should be at least two legal persons namely Mother company and dependent company so the multinational title would be true about it and the mother company and dependent company can be formed in each country in compliance with the specific rules of the company's registration country and add a new member under the title of dependent company to the existing entity. It should be noted, transactions between multinational companies are not limited to a specific geographic area (Schmitthoff, 2011, pp. 489-499) and activity of the dependent company is along with the Mother Company's objectives and of course by exerting the view to the company shareholders.

The members of the group have unlimited common liability in exchange for the debts of the company, of course, the responsibility, is secondary. Because according to Article 24 of European Union (Note 10), at first, the group 
will be responsible and if the assets of the company were not enough for the debts of the company, then the members will be responsible. Article 24 does not make any distinction between members and all members are equally responsible for paying their debts. Because the group's secondary and main business activities, are managed and controlled by all the members of the group and all have equal role in this area. Granting unlimited joint liability to the members represents basic different national laws of companies in connection to this subject in Europe. A German private company with limited liability is responsible for 25,000 euros, but another company especially English Company with limited liability may be responsible for a lot less than this amount. About the financial distress of a multinational company, should say that the proceedings shall be subject to a bankruptcy regime even if there are several states claim jurisdiction (Tung, 2001). Therefore, by means of the legal person separates from the Mother Company and also the Dependent Company should say that in principle, debt or bankruptcy of one of them is not in contact with the other.

As mentioned above and the way of profits and losses of the group must also said that the way of dividing profits and losses of this group are usually subject to contract of creating these groups and in case of non-mentioning the rules in this area, the way of dividing profits and losses will be equal and the members' rights and obligations are also determined in the same way.

\section{Conclusions}

According to above mentioned issues about European Economic Interest Group, the EEIG is a legal framework which aimed at promoting and facilitating cooperation among entrepreneurs that can make profits for its members. Group is very flexible and a separate legal instrument, so that some of the rules can be determined by its members in abiding some of the guidance in European Union regulations. And even a group like the company, can manage its business and has trademark. Politics in the group has based with regard to the economic development of Europe and therefore as far as possible has tried to remove the barriers in the creation and management of its activities and it should be noted approaching that this Supportive approach, is the starting point for the reason of differing to multinational companies.

In multinational companies, the main goal is profit and profitability and with regard to this issue, the Circuit Company has made a move to establish subsidiary or dependent companies and the target countries allow these companies to be present with exact scrutiny and sometimes with strict regulations. And overall, the method and position of these two entities cannot be placed in one direction.

Philosophy of creation the Economic Interest Group, is facilitating and promoting economic and commercial activity. Because for the business especially for the smaller agencies, other development options such as integrations or establishing a company may be very expensive and complicated and so that the group removes most of its member's needs. Economic interest group like the company may be domestic or international. It means that its members can be from different nationalities. European Economic Interest Group is created to help the creation of business and trade and also to improve the connection with companies and agencies which are in the other member countries and its goal is facilitating and improving its members' economic activities by means of integration of resources, activities and skills and this can make better results than the activity a person does alone. With these words, the group is placed in the category of international business law and represents all of the regulations governing the cross-border economic activity. European Economic Interest Group, only holds between European countries while the multinational companies don't have any limitation. For example, a mother Company in Europe can establish a subsidiary company in Asia.

As seen in the above passage, formation of European Economic Interest Group pursues another aim basically, because it steps to achieve business prosperity and to expand economic activities of its members and people have more supportive look to it which is combined with the flexibility, while in the case of multinational companies because of the fears there are about these companies' influence and their penetration in political and economic and cultural context of the host country, it is usually combined with restrictions and if a country accepts that the mother company can establish the subsidiary company in its territory, it's because of the mutual need and these are constantly trying to impose conditions that preventing the full control of these companies over the institution of sovereignty and power structures that are in it. As stated purpose and approach, two groups are different from each other and including the differences will be explained in the following cases:

-In the Economic Interest Group, two or more natural or legal person create it who have mutual benefits, however, to form a multinational company they need at least two legal persons under the Mother company and dependent company. 
-European Economic Interest Group, only flows and holds between European countries while there is not this limit in the multinational companies. For example, a mother company in Europe can establish a subsidiary company in Asia.

-European Economic Interest Group is not formed with the aim of making a profit while the multinational company is based on profit and profitability.

-In the European Economic Interest Group, exerting management control over the members' activities or other responsible people is forbidden while in the multinational company, the mother company influences on the subsidiary company under the management contracts or having a higher stock.

\section{References}

Council Regulation (EEC). (2000). No. 2137/85 on the European Economic Interest Grouping Implementation Act Passed, 53, 342. Retrieved from https://www.riigiteataja.ee/en/eli/530102013073/consolide

Department of Economic and Social Affairs of United Nations. (1973). Multinational Corporations in World Development. United Nation Publication: New York.

European Economic Interest Grouping (EEIG). (1985). Council Regulation (EEC) No 2137/85 of 25 July 1985 on the European Economic Interest Grouping (EEIG). Retrieved from http://europa.eu/legislation summaries/internal_market/businesses/company_law/126015_en.htm

European Economic Interest Grouping, Principal Act, Act. No. 1993-28 EU Legislation/International Agreements involved: Directive 68/151/EEC. Published by: Government of Gibraltar. Retrieved from http://www.gibraltarlaws.gov.gi

European Economic Interest Groupings - GPO4, August 2013- Version 2.4. Retrieved from http://www.companieshouse.gov.uk/about/gbhtml/gpo4.shtml

Grossman, E. (2003). Bringing Politics Back In: Rethinking the Role of Economic Interest Groups in European Integration, Les Cahiers européens de Sciences Po, n 02, Paris: Centre d'études européennes at Sciences Po.

Meiselles, M. (2013). The European Economic Interest Grouping - A Chance for Multinationals? Accessed in. http://works.bepress. com/michala_meiselles/3

Mesnooh, C. J. (1994). Law and Business in France: A Guide to French Commercial and Corporate Law. Leiden, Netherlands: Martinus Nijhoff Publishers.

Mevorach, I. (2008). The Home Country of A multinational Enterprise Group Facing Insolvency. International and Comparative Law Quarterly, 57(2), 427-448. http://dx.doi.org/10.1017/S0020589308000250

Ngomba-Roth, R. (2007). Multinational Companies and Conflicts in Africa: The Case of the Niger Delta, Nigeria. LIT Verlag, Münster.

Santa, M. A. (2009). European Economic Law (2nd ed.). Alphen Aan Den Rijn, Netherland.

Schmitthoff, C. M. (2011). The Law and Practice of International Trade (translate to Persian: Behrouz Akhlaghi et al., Vol. 1). Tehran: Samt Publication.

Shiravi, A. H. (2011). International Business Laws. Tehran: Samt Publication.

Sitaru, D. A., \& Sitaru, D. A. (2011). Corporations and Partnerships in Romania, Kluwer Law International. Alphen Aan Den Rijn, Netherland.

Storm. P. M. (1971). A New Impulse toward a European Company. The Business Lawyer, 26(5), 1443-1453.

The Council of the European Communities. (1985). Regulation on the European Economic Interest Grouping (EEIG), (EEC) No 2137/85 of 25 July 1985. The Council of the European Communities Official Journal L 199, 31/07/1985 P. 0001 - 0009. Retrieved from http://eur-lex.europa.eu/LexUriServ/LexUriServ.do?uri= CELEX:31985R2137:en:HTML

Tung, F. (2005). Fear of Commitment in International Bankruptcy (June 25, 2001). http://dx.doi.org/10.2139/ ssrn. 277394

Warner, P. J., \& Schmitz, M. (2004). Luxembourg in International Tax Planning. Amsterdam: IBFD.

Zaker Hussein, A. R. (2001). Transnational Companies. School of law and Political science Journal, 61(3), $100-142$. 


\section{Notes}

Note 1. European Economic Interest Group.

Note 2. Article 40 of EEIG Regulation: The profits or losses resulting from the activities of a grouping shall be taxable only in the hands of its members.

Note 3. Joint-Venture: Joint venture refers to a type of business partnership in which both parties manage certain activities in common and the resulting gains and losses are shared. This type of cooperation is wide spread in the world. For More Information See: Ancient A. and J. Rezaei, Economic impacts of establishing an economic group with the formation of the Joint Venture based on common interests, Vice President of Planning and Economic Affairs, Bureau of Economic Research, January 1387.

Note 4. http://europa.eu/legislation_summaries/internal_market/businesses/company_law/126015_en.htm

Note 5. Art.30 of the law of 25 march 1991 on Economic Interest Grouping and art.14 of the law of 25 march 1991 on European Economic Interest Groupings.

Note 6. Double signature means that EEIG activities are done only by joint action of two or more managers, and in fact it is a control means.

Note 7. According to the members' agreement, the profit is invested in the group or is divided between group members and can also be converted into reserves of the group.

Note 8. Article 40: The profits or losses resulting from the activities of a grouping shall be taxable only in the hands of its members.

Note 9. EEIG (Europe economic interest grouping), the only transnational legal instrument for co-operation between entrepreneurs in Europe, libertas_European institute GmbH, European EEIG Information Centre, RA Hans-Jurgen Zahorka, Untere Vorstadt 11, D-71063 Sindelfingen (Stuttgart).

Note 10. Article 24: 1 . The members of a grouping shall have unlimited joint and several liability for its debts and other liabilities of whatever nature. National law shall determine the consequences of such liability. 2. Creditors may not proceed against a member for payment in respect of debts and other liabilities, in accordance with the conditions laid down in paragraph 1 , before the liquidation of a grouping is concluded, unless they have first requested the grouping to pay and payment has not been made within an appropriate period.

\section{Copyrights}

Copyright for this article is retained by the author(s), with first publication rights granted to the journal.

This is an open-access article distributed under the terms and conditions of the Creative Commons Attribution license (http://creativecommons.org/licenses/by/3.0/). 